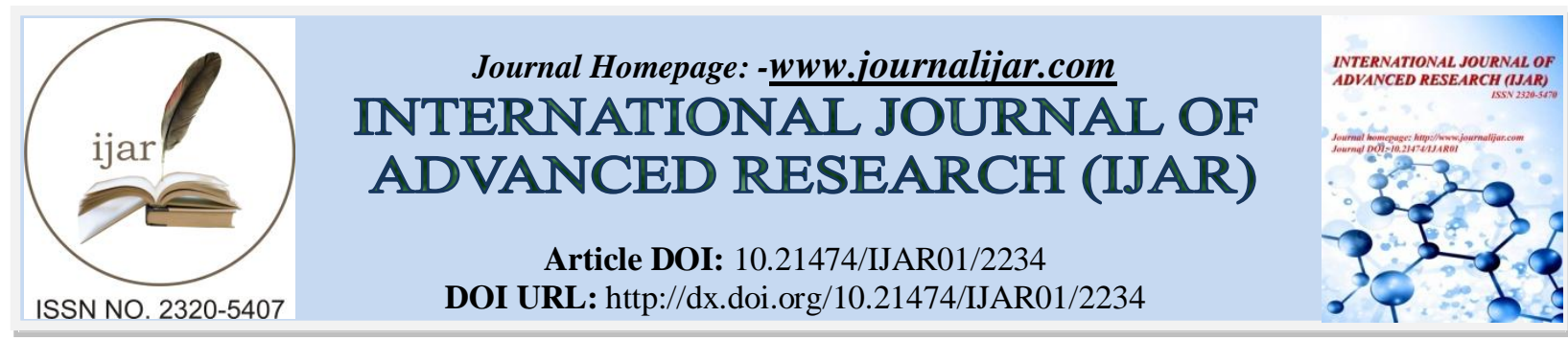

RESEARCH ARTICLE

\title{
EFFECT OF CHEMICAL PRESERVATIVES ON SHELF LIFE OF COSMOS SULPHREUS CAV. CUT FLOWER.
}

Ruby Patel, Munjal Parmar, Meghna Bhatt and Shivangi Mathur.

Assistant Professor, President Science College, Gujarat University, Ahmedabad.

\section{Manuscript Info}

Manuscript History

Received: 29 September 2016

Final Accepted: 30 October 2016

Published: November 2016

Key words:-

Cosmos sulphreus, Chemical Preservative, Shelf life, Sucrose, Citric acid.

\begin{abstract}
Keeping quality is an important parameter for evaluation of cut flower quality, for both in export and domestic markets. Holding solution should contain chemical preservatives to prolong the vase-life of cut flowers. These holding solutions must contain germicide to control harmful bacteria and prevent plugging of the conducting tissues. For many years, floral preservatives have been acidified and have usually included biocides to inhibit bacterial proliferation. The sugars provide a respiratory substrate, while the germicides control harmful bacteria and prevent plugging of the conducting tissues. For flower opening, large amount of soluble carbohydrates is required as the substrate for respiration and synthetic materials as well as osmolytes. Present study was carried out for Cosmos sulphreus Cav. Cut flowers. Various chemical preservatives were used to prolong shelf life of cut flower of Cosmos sulphreus. Among them citric acid + sucrose maintain same water balance as compare to the D.W. but increased shelf life by 1 day i.e. 5 days.
\end{abstract}

Copy Right, IJAR, 2016,. All rights reserved.

\section{Introduction:-}

India has an ancient heritage when it comes to floriculture. India is the second largest producer of flowers after China (Mathur and Pachpande, 2013). Floriculture products consist of cut flowers, loose flowers, potted plants, plant rentals, seeds, bulbs, tubers, rooted cuttings and dried flowers or leaves. Floriculture products are classified in two categories: Cut flowers and foliage; Plants and young plant material including bulbs, tubers, tuberous roots, rhizomes, corms, flowering plants, rooted and un-rooted cuttings. Among all products cut flowers are in considerable demand in both domestic and export markets. Besides floral arrangements, Cosmos is widely used in bouquets and in dry flower crafts. The cut flowers have a long vase-life, which fetches premium market prices. Keeping quality is an important parameter for evaluation of cut flower quality, for both domestic and export markets.

Prolonging vase life of cut flower is one of the most important aspect fields of floristry (Umebeseet al., 2010). Among all flower organs, petals primarily determine the commercial longevity of the flowers and as a result much attention has been given to the physiological and biochemical processes that occur during petal senescence. Petal senescence is visibly shown by wilting or withering which vary depending on the species. Wilting of petals is due to loss of turgidity while withering is a colour change and slow dehydration. In most of the species flowers shows visible symptoms of senescence, i.e. the petals will abscise, also the time between visible symptoms and abscission is quite variable. In some species like Carnation, abscission takes place much later than visible senescence while in 
Tulip, visible senescence and abscission occur at about the same time. Prolonged vase life is one of the most important factors for quality of cut flowers. Senescence of cut flowers is induced by several factors $e$.g., water stress (Sankat\&Mujaffar, 1994), carbohydrate depletion (Ketsa, 1989), microorganisms (van Doorn\& Witte, 1991) and ethylene effects (Wu et al., 1991).

Addition of chemical preservatives to the holding solution is recommended to prolong the vase-life of cut flowers. All holding solutions must essentially contain two components viz., sugar and germicides. Therefore, the techniques of prolonging the vase-life of flowers will be a great asset to the growers and users. A major cause of deterioration in cut flowers is blockage of xylem vessels by microorganisms that accumulate in the vase solution or in the vessels themselves. For many years, floral preservatives have been acidified and have usually included biocides to inhibit bacterial proliferation (Nowak \&Rudnicki, 1990). The sugars provide a respiratory substrate, while the germicides control harmful bacteria and prevent plugging of the conducting tissues. For flower opening, large amount of soluble carbohydrates is required as the substrate for respiration and synthetic materials as well as osmolytes.

\section{Material and Method:-}

Flowers were harvested when all the florets opened fully and were perpendicular to the stalk. The flowers were harvested early in the morning and were immediately placed in water for pre-cooling. The stalks were cut again prior to placing them in holding solution to study the keeping quality. Glass test tubes were used to hold the floral preservatives and a uniform volume of $50 \mathrm{ml}$ of holding solution was prepared freshly and dispensed into the tubes. The tubes were kept at room temperature and with adequate aeration. The flowers were placed away from direct sunlight. Holding solutions with different chemical preservative were used and the experiment was conducted in completely randomized design with three replications (Table 1).

\section{Results and discussion:-}

During present study distilled water (DW) as preservative solution was the control set and the flowers kept in distilled water under cut conditions were selected further for conducting biochemical studies. Total water uptake, total transpiration water loss, total water balance and shelf life of flower in days are shown in Table- 1 . As shown in the table- 1 different chemicals and their combinations have proved beneficial in enhancing the shelf life of Cosmos sulphreus Cav. by possibly causing some alteration at the biochemical level of flower that improve water balance in the petals.

Table-1:- Showing effect of chemical preservatives on various parameters to study post harvest shelf life of cut Cosmos sulphreusCav.

\begin{tabular}{|c|c|c|c|c|}
\hline Treatment & $\begin{array}{l}\text { Total } \\
\text { transpiration } \\
\text { water loss } \\
\text { (In gm/flower/day) }\end{array}$ & $\begin{array}{l}\text { Total water } \\
\text { uptake } \\
\text { (In } \\
\text { gm/flower/d } \\
\text { ay) }\end{array}$ & $\begin{array}{l}\text { Total water } \\
\text { balance } \\
\text { (In } \\
\text { gm/flower/d } \\
\text { ay) }\end{array}$ & $\begin{array}{l}\text { Shelf life in } \\
\text { Days } \\
\text { (In } \\
\text { gm/flower/ } \\
\text { day) }\end{array}$ \\
\hline D.W. & 6.58 & 6.30 & -0.26 & 4 \\
\hline Sucrose $(1 \%)$ & 10.47 & 9.52 & -0.95 & 5 \\
\hline Citric Acid (100 ppm) & 10.23 & 8.86 & -1.37 & 5 \\
\hline Citric Acid (100 ppm) + Sucrose (1\%) & 5.81 & 5.55 & -0.26 & 5 \\
\hline MH (100 ppm) & 6.89 & 6.41 & -0.48 & 5 \\
\hline $\begin{array}{l}\text { MH (100 ppm) + Aluminum sulphate }(100 \\
\text { ppm })+ \text { Sucrose }\end{array}$ & 9.47 & 8.64 & -0.83 & 5 \\
\hline $\begin{array}{l}\text { MH }(100 \mathrm{ppm})+\text { Sodium benzoate }(100 \mathrm{ppm}) \\
+ \text { Sucrose }(1 \%)\end{array}$ & 8.62 & 7.32 & -1.3 & 5 \\
\hline $\begin{array}{l}\text { MH }(100 \mathrm{ppm})+\text { Citric Acid }(100 \mathrm{ppm})+ \\
\text { Sucrose }(1 \%)\end{array}$ & 8.82 & 7.56 & -1.26 & 5 \\
\hline $\begin{array}{l}\text { MH (100 ppm) + Aluminum sulphate } \\
(100 \mathrm{ppm})\end{array}$ & 11.43 & 10.28 & -1.15 & 5 \\
\hline MH $(100 \mathrm{ppm})+$ Sodium benzoate $(100 \mathrm{ppm})$ & 7.32 & 6.52 & -0.8 & 5 \\
\hline MH (100 ppm) + Citric Acid (100 ppm) & 10.17 & 9.38 & -0.79 & 5 \\
\hline MH (100 ppm) + Sucrose (1\%) & 6.74 & 6.44 & -0.3 & 5 \\
\hline Citric Acid $(100 \mathrm{ppm})+$ Sucrose $(1 \%)$ & 5.83 & 4.81 & -1.02 & 5 \\
\hline
\end{tabular}




\begin{tabular}{|l|l|l|l|l|}
\hline +Sodium benzoate $(100 \mathrm{ppm})$ & & & & \\
\hline $\begin{array}{l}\text { Citric Acid }(100 \mathrm{ppm})+\text { Aluminum sulphate } \\
(100 \mathrm{ppm})+\text { Sucrose }(1 \%)\end{array}$ & 10.54 & 9.24 & -1.3 & 5 \\
\hline $\begin{array}{l}\text { Citric Acid }(100 \mathrm{ppm})+\text { Sodium benzoate } \\
(100 \mathrm{ppm})\end{array}$ & 9.41 & 8.74 & -0.67 & 5 \\
\hline $\begin{array}{l}\text { Citric Acid }(100 \mathrm{ppm})+\text { Aluminum sulphate } \\
(100 \mathrm{ppm})\end{array}$ & 6.45 & 5.84 & -0.61 & 5 \\
\hline Sodium benzoate & 6.14 & 5.84 & -0.3 & 5 \\
\hline
\end{tabular}

Many researchers have shown that shortage of soluble carbohydrate in petals is one of the most important causes for shortening vase life of cut flowers, so addition of sucrose in vase solutions increases flower longevity. Delaying protein degradation, controlling respiration, higher water uptake and inhibition of ethylene production in cut flowers are the other advantages of sugars Ichimuraet al., 1999; Ichimuraet al., 2006; Ichimuraet al., 2003; Liao et al., 2000 support the result of present research work that flowers preserve well in vase solution containing sucrose showing maximum water uptake than other preservatives. Similar results were also reported by Steinitz (1982) and Awadet al., (1986) in Gerbera and Zinnia, respectively.

The water balance in the flower petals is the most crucial aspect for post harvest shelf life. MH, Citric acid, Sucrose, Sodium Benzoate, Aluminum sulphate and in combination have been found to influence water balance. The aesthetic shelf life of Cosmos sulphureuswas 5 days in all these sets and water balance seen in Citric acid + Sucrose is similar to DW set but shelf life had increased be one day, like wise MH + Sucrose shows good water balance and improved shelf life and so on.

During experiment it was observed that preservative solutions $\mathrm{MH}(100 \mathrm{ppm})$ and citric acid (100 ppm) with sucrose (1\%) showed more water balance than the without addition sucrose (1\%) solution. More water balance helps cut flower to extend shelf life. Steinitz (1982) opined that addition of sucrose to the solution increased the mechanical rigidity of the stem by inducing cell wall thickening and lignification of vascular tissues. Sugars alone, however, tends to promote microbial growth. The blockage of the base of stem due to bacterial plugging results in decrease of water uptake by stem. A very high level of turgidity is necessary for continuation of normal metabolic activities in the cut flowers. Organic acids play an important role in reducing the $\mathrm{pH}$ in preservative formulation. Generally, citric acid is used to lower the $\mathrm{pH}$ of vase solutions for Gladiolus glandiflorus L (Hunter et al., 2004). Citric acid prevents the plugging of vascular tissue thus results in improved water balance and enhanced the intensity of petal colour probable by changing the $\mathrm{pH}$ of cell sap. Use of citric acid at $0.5-0.7 \%$ in holding solution promoted the floral development and keeping quality of cut spikes of tuberose (Leivet al., 2005). Leivet al., 2005, also suggested that aluminiumsulphate can be used as a germicide in floral preservation. Waithakaet al., 2001, attributed the effect of aluminium to lowering the $\mathrm{pH}$ of rose petals and stabilizing the anthocynins, thereby improving the keeping quality of rose cut flower. It has been reported that aluminum sulfate extended vase life and improved water relation and postharvest quality of cut rose flowers by antimicrobial effect (Edrisi, 2003; Ichimura and Ueyama, 1998).

Some vase solutions including sucrose extend the vase life of cut flowers (Kuiper et al., 1995; Ichimura\&Korenaga, 1998). Floral preservative solution containing aluminum sulfate at $150 \mathrm{mg} \mathrm{L}-1$ under $25^{\circ} \mathrm{C}$, extended cut eustoma (EustomagrandiflorumShinn. cv. HeiHou) vase life (Liao et al., 2001). The effect of other chemical treatment in increasing vase life of some cut flowers has been suggested by many authors (Saradhi\& Ram, 1989; Ichimura\&Korenaga, 1998; Van Meeterenet al., 2000). Therefore, the vase life varied among various cultivars in carnation (Wu et al., 1991; Onozakiet al., 2001) and gerbera (Wernettet al., 1996).

The purpose of the present study was determining cultivar responses of Chrysanthemum cut flowers to different chemical treatments in order to increase their post-harvest vase life of Chrysanthemum cut flowers. It has been suggested that use of disinfectants improve water conductance by preventing bacterial growth and producing occlusions (Van Doorn, 1998). In addition to HQS, many germicides, such as silver nitrate, aluminum sulfate, copper sulfate, cobalt chloride etc have been shown to inhibit bacterial growth in cut flower stems (Van Doorn, 1997). Whether these chemicals are effective for various cultivars needs to be examined because it was suggested that uptake of different solution (Ichimuraet al., 2002), ethylene production (Branadt\& Woodson, 1992) carbohydrate (Ketsa, 1989) and transpiration (Ichimuraet al., 2002) between cultivars could be the causes of variation in vase life. 
Ichimura and Hiraya (1999) reported that treatment with sucrose extends the vase life of florets harvested at a bud stage. Cut flowers treatment with sugars increases the availability of respirable substrates (Da Silva, 2003), delay the onset of hydrolysis of structural cell components (Donoghue et al., 2002), decrease ethylene production and sensitivity (Pun et al., 2005). Treatment with sucrose in combination with chemical treatments extends the vase life of cut Chrysanthemum flowers. This effect is due to supply of carbohydrates as well as inhibition of vascular occlusion by chemical treatments.

\section{Conclusion:-}

Irreversible complex changes occurring at the physiological and biochemical levels results into the termination of shelf life, hence it promotes the study of senescence and post harvest research. During post harvest study it was observed that under cut condition having D.W. alone as holding solution, flower lived for 4 days with 4 th day as the senescence stage. During post harvest experiments, flowers kept in different chemical preservative solutions. Among them Citric acid $(100 \mathrm{ppm})+$ Sucrose $1 \%$ showed same water balance as compare to D.W. but increased shelf life by 1 day i.e. 5 days.

\section{Acknowledgment:-}

Author thanks Dr. A. U. Mankad, Professor and Head, Department of Botany, University School of Sciences, Gujarat University for providing laboratory facilities. And also thank DST, New Delhi for providing necessary funding.

\section{References:-}

1. Awad, A.R.E., Meawad, A., Dawh, A. K. and El-saka. (1986): Cut flower longevity as affected by chemical pretreatment. J. Ornamental Hort., 181: 177- 193.

2. Branadt, A.S. and Woodson, W.R., (1992): Variation in flower senescence and ethylene biosynthesisamong carnations. Hort. Sci., 27: 1100-102.

3. Da Silva, J.A.T., (2003): The Cut Flower: Postharvest Considerations. Biol. Sci., 3: 406-42.

4. Donoghue, E.M., Somerfield, S.D. and Heyes, J.A., (2002): Vase solutions containing sucrose result in changes to cell walls of sandersonia (Sandersoniaaurantiaca) flowers. Postharv. Biol. Technol., 26:285-94.

5. Edrisi, B. (2003): Effects of chemical solutions on life lasting and other quality characteristics of postharvest in rose (Rosa hybridacv. Illona). Abstracts of 2nd Applied and Scientific Seminars on Ornamental Plants and Flowers of Iran. Iran.

6. Han, S.S., (2003): Role of sugar in vase solution on postharvest flower and leaf quality of Oriental Lily Stargazer. Hort. Sci., 38: 412-6.

7. Hunter, D. A., Yi, M., Xu., X. and Ried, M. S. (2004): Role of ethylene in perianth senescence of daffodil (Narcissus pseudonarcissusL. 'Dutch Master'). Postharv. Bio. andTechn.,32: 269-280.

8. Ichimura, K. and Korenaga, M. (1998): Improvement of vase life and petal color expression in several cultivars of cut Eustomaflowers using sucrose with 8-hydroxyquinoline sulfate. Bull. Natl. Res. Veg. Ornam. Pl. Tea Japan, 13: 31-9.

9. Ichimura, K. and Hiraya, T. (1999): Effect of silver thiosulfate complex (STS) in combination with sucrose on the vase life of cut sweet pea flowers. Hort. Sci., 68: 23-7.

10. Ichimura, K. and Ueyama, S. (1998): Effects of temperature and application of aluminum sulfate on the post harvest life of cut rose flowers. 13: 51-60.

11. Ichimura, K., Kawabata Y., Kishmoto M., Goto R. and Yamad K., (2002): Variation whit the cultivar in the vase life of cut flowers. Bull. Natl. Inst. Flor. Sci., 2: 9-20.

12. Ichimura, K., Kawabata, Y., Kishimoto, M., Goto, R. and Yamada, K., (2003): Shortage of soluble carbohydrates is largely responsible for short vase life of cut 'Sonia' rose flowers. Journal of Japan society of Horticultural science.72: 292-298.

13. Ichimura, K.; Kojima, K. and Rie, G. (1999): Effect of temperature, 8- hydroxyquinolinesulphate and sucrose on vase life of cut rose flowers. Postharvest Biology and Technology. 15:33-40.

14. Ichimura, K., Taguchi, M. and Norikoshi, R. (2006): Extension of vase life in cut roses by treatment with glucose, isothiazolinonic germicide citric acid and aluminum sulphate solution. Japan Agricultural Research Quarterly. 40: 263-269.

15. Ketsa, S., (1989): Vase life characteristics of inflorescences of dendrobium 'Pompadour. Hort. Sci., 64: 611-5.

16. Kim, H.J., Craig, R. and Brown, K.M., (2005): Genetically enhanced postproduction in quality in regal pelargonium. Acta Hort., 669: 135-42. 
17. Kuiper, D., Ribot, S., Van Reenen, H.S. and Marissen, N., (1995): The effect of sucrose on the flower bud ripening of 'Madelon'cut roses. Sci. Hort., 60: 325-6.

18. Leiv, M. M. and Hans, R. G. (2005): Effect of air humidity variation on powdery mildew and keeping quality of cut roses. Sci. Hort., 140: 49-55.

19. Liao, L.J., Lin, Y.H., Huang, K.L. and Chen, W.S., (2001): Vase life of Eustomagrandiflorumas affected by aluminum sulfate. Bot. Bull. Acad. Sin., 4: 35-8.

20. Mathur, R. and Pachpande, P. (2013): Floriculture - Prospects and opportunities. ASM's International EJournal of Ongoing Research in management and IT, 13 (21): 1-10.

21. Nowak, J. and Rudnicki, R.M., (1990): Postharvest Handling and Storage of Cut Flowers, Florist Greens and Potted Plants, p: 210. Timber Press, Porthand, Oregan.

22. Onozaki, T., Ikeda, H. and Yamaguchi, T. (2001): Genetic improvement of vase life of carnation flowers by crossing and selection. Sci. Hort., 87: 107-20.

23. Pun, U.K., Shimizu, H., Tanase, K. and Ichimura, K., (2005): Effect of sucrose on ethylene biosynthesis in cut Carnation flowers. Acta Hort., 669: 171-4.

24. Sankat, C.K. and Mujaffar, S., (1994): Water balance in cut anthurium flowers in storage and its effect on quality. Acta Hort., 368: 723-32.

25. Saradhi, P.P. and Ram, H.Y.M., 1989. Prolongation of vase life chrysanthemum blooms by cobalt chloride and its reversal by IAA. ISHS Acta Hort., 261: 309-12.

26. Steinitz, B. (1982): Role of sucrose in stabilization of cut Gerbera flower stalks. Gartenbouwissenschaft, 47(2): $77-81$.

27. Umebese, C. E.; Oji, C. K. and Osinaike, T. S. (2010): Phenological and physiological changes induced by extending vase life of cut flowers of AllamandacatharticaL. var. gradiflora. Journal of Sci. Res. Dev.,12:1-9.

28. Van Doom, W.G. and Witte, Y. De., (1991): The mode of action of bacteria in the vascular occlusion of cut rose flowers. Acta Hort., 298: 165-7.

29. Van Doorn, W.G., (1997): Water relations of cut flowers. Hort. Rev., 18: 1-85.

30. Van Doorn, W.G., (1998): Effects of daffodil flowers on the water relations and vase life of roses and tulips. J. American Soc. Hort. Sci., 123: 146-9.

31. Van Meeteren, U., Van Gelder, H. and Van Ieperen, W., (2000): Reconsideration of the use of deionized water as vase water in postharvest experiments on cut flowers. Postharv. Biol. Technol., 18: 169-81.

32. Waithaka, K.; Reid, M. S. and Dodge, L. L. (2001): Cold storage and flower keeping quality of cut tuberose (PolianthestuberosaL.). J. Hort. Sci. And Biotechn., 76: 271-275.

33. Wernett, H.C., Wilfret, G.J., Sheehan, T.J., Marousky, F.J., Lyrene, P.M. and Knauft, D.A., (1996): Postharvest longevity of cut-flower Gerbera. I. Response to selection for vase life of components. J. American Soc. Hort. Sci., 121: 216-21.

34. Wu, M.J., Van Doom, W.G., and Reid, M.S., (1991): Variation in the senescence of carnation (Dianthus caryophyllusL.) cultivars. II. Comparison of sensitivity to exogenous ethylene and of ethylene binding. Sci. Hort., 48: 109-16. 